\title{
CONTINUOUS MEASUREMENTS OF HYDROGEN PEROXIDE, FORMALDEHYDE, CALCIUM AND AMMONIUM CONCENTRATIONS ALONG THE NEW GRIP ICE CORE FROM SUMMIT, CENTRAL GREENLAND
}

\author{
Katrin Fuhrer, ${ }^{*}$ Albrecht Neftel, ${ }^{*}$ Martin Anklin, ${ }^{*}$ and Valter Maggi $\dagger$ \\ * Physikalisches Institut, Universität Bern, Sidlerstrasse 5, Bern 3012, Switzerland and †Dipart. di Scienze \\ della Terra, Via Mangiagalli 34, Milano 20133, Italy
}

(First received 31 October 1992 and in final form 2 March 1993)

\begin{abstract}
A new deep core drilling operation started in 1990 in central Greenland and in 1992 reached the bottom at a depth of $3028 \mathrm{~m}$.b. surface. Taking advantage of recent developments in the analytical technique of chemical trace species, continuous high resolution measurements of $\mathrm{H}_{2} \mathrm{O}_{2}, \mathrm{HCHO}, \mathrm{NH}_{4}^{+}$and $\mathrm{Ca}^{2+}$ concentrations were performed directly on the ice core in the field. During the 1991 season all four components were measured simultaneously between $1300 \mathrm{~m}$.b. surface and $2300 \mathrm{~m} . \mathrm{b}$. surface, corresponding to the time interval between 8000 and 38,000 years B.P. In this paper an overview of the results and our first interpretations in terms of climatic changes are given.
\end{abstract}

Key word index: Polar ice cores, glacial interstadials, palaeo climatic changes, flow injection analysis.

\section{INTRODUCTION}

Ice cores record changes in concentrations of chemical species over time scales ranging from intra-annual to glacial-interglacial transitions. The changes in the ice are thought to largely reflect changes in atmospheric chemistry and dynamics resulting from variations in biogeochemical cycling. There is a long list of parameters in ice cores that can be used to describe the evolution of climate in the past (see e.g. Oeschger and Langway, 1989).

Reconstructing past climatic variations, as reflected in polar ice cores, is one of the few possible validations of models attempting to describe future climatic changes caused by anthropogenic emissions.

In 1990 a joint European deep drilling project (GRIP) started at Summit, the highest point on the Greenland ice sheet. The drilling operation reached bedrock in July 1992 after penetrating $3028 \mathrm{~m}$ of ice. The expected simple flow pattern (no horizontal movement) and a low mean annual temperature, combined with a yearly accumulation rate of about $20 \mathrm{~cm}$ water equivalent in present day conditions, promised good conditions for palaeoclimatic investigations.

Simultaneous high resolution measurements of $\mathrm{H}_{2} \mathrm{O}_{2}, \mathrm{HCHO}, \mathrm{NH}_{4}^{+}$and $\mathrm{Ca}^{2+}$ were performed from a depth of $1300 \mathrm{~m}$ to the bottom of the core. Data from the depth interval between 1300 and $2300 \mathrm{~m}$, which were measured in 1991, are presented here.

A variation in the measured concentration of a chemical trace component in the ice cannot be directly related to a corresponding variation in the atmospheric concentration or the associated source concentration. The concentration of a trace species in ice will be modulated by changes in source strength, the transfer behaviour from atmosphere to snow and postdepositional changes. The four measured species presented in this paper differ in their transfer and postdepositional behaviour. A possible coarse classification of chemical species in polar ice can be made by their exchange properties at the air-snow interface. Gaseous species like $\mathrm{HCHO}$ or $\mathrm{H}_{2} \mathrm{O}_{2}$ are deposited reversibly: the exchange between snow and atmosphere continues on the surface after deposition, influencing the recorded concentration. Aerosol-related species (e.g. $\mathrm{Ca}^{2+}$ and $\mathrm{NH}_{4}^{+}$) are irreversibly deposited to the snow surface: their concentration will not be changed by redistribution processes on a molecular scale. However, the initially deposited amount of an aerosol species might be affected by redistribution processes on a macro scale, i.e. wind-blown snow etc. (Dibb et al., 1992).

\section{CHARACTERIZATION OF THE MEASURED SPECIES}

The atmospheric concentrations of $\mathrm{H}_{2} \mathrm{O}_{2}$ and $\mathrm{HCHO}$ are linked to the $\mathrm{OH}$ radical concentration, which determines to a large extent the atmospheric oxidation capacity (Thompson, 1992). The oxidation capacity determines the atmospheric lifetime of many trace species such as $\mathrm{CH}_{4}$ and $\mathrm{CO}$ that influence the radiation balance and therefore the climatic conditions. $\mathrm{H}_{2} \mathrm{O}_{2}$ is especially well suited as a control to test atmospheric chemistry models (see e.g. Kleinmann, 1986). A historical record of the mean atmospheric concentration at high latitude yields useful constraints for predicting changes to the chemical system in the atmosphere based on various climatic or emission scenario (Thompson et al., 1989). 
In remote regions, $\mathrm{HCHO}$ is mainly produced in the oxidation chain of $\mathrm{CH}_{4}$, initiated by the reaction with $\mathrm{OH}$ radicals. Because the historical record of the atmospheric concentration of $\mathrm{CH}_{4}$ is known from the measurements of air enclosed in the bubbles, an atmospheric record of $\mathrm{HCHO}$ in principle gives the opportunity to derive a record of the $\mathrm{OH}$ concentrations over Greenland (Staffelbach et al., 1991).

$\mathrm{NH}_{4}^{+}$concentrations originate from $\mathrm{NH}_{3}$ emissions, which have predominantly continental sources of biogenic origin, mainly bacterial decomposition in soils and biomass burning (Legrand et al., 1992).

$\mathrm{Ca}^{2+}$ is transported to Greenland with dust particles, mostly carbonate, and to a lesser extent with sea salt particles (Whitlow et al., 1992). Calcium carbonate and $\mathrm{NH}_{3}$ in the atmosphere are the two species that are capable of neutralizing acids. Core sections that have alkaline properties, i.e. $\mathrm{pH}$ of the melted ice $>7$, also have large calcium and/or ammonium levels. Calcium carbonate in the ice is also suspected of interfering with the $\mathrm{CO}_{2}$ concentration, as a result of the possible release of $\mathrm{CO}_{2}$ by reaction with strong acids (Delmas, 1993, in press).

\section{EXPERIMENTAL}

A continuous melting technique, combined with continuous flow analysis, has been developed for measurements of chemical trace species in ice cores directly in the field (Sigg et al., 1993, submitted for publication). A subcore with a cross section area of $18 \times 18 \mathrm{~mm}^{2}$ cut from the main core is needed for the simultaneous analysis of the four components. The subcore is melted continuously from one side at a constant rate. The main advantage of this method, compared to conventional sampling and analytical procedures of discrete samples, are given by the high spatial resolution (ca. $1 \mathrm{~cm}$ for $\mathrm{H}_{2} \mathrm{O}_{2}, \mathrm{NH}_{4}^{+}$and $\mathrm{HCHO}$; ca. $3 \mathrm{~cm}$ for $\mathrm{Ca}^{2+}$ ) combined with a significant reduction in sample handling. The spatial resolution is only limited by the sample dispersion in the melting system and the analyser.

The subcore, with a maximum length of $250 \mathrm{~cm}$, is mounted vertically in the sample holder, which holds the sample centred over the melting device, a heated aluminium cylinder. The geometry of the melting device allows a separation of the meltwater into an inner and an outer fraction. The inner fraction originates from subcore ice that (except for ends and breaks) has not been exposed to the present day atmosphere, whereas the outer fraction includes ice from the subcore surface. For the analysis of species that are sensitive to contamination, $\mathrm{HCHO}, \mathrm{NH}_{4}^{+}$and $\mathrm{Ca}^{2+}$, the inner fraction has to be used for the analysis. For species that are not sensitive to contamination, e.g. $\mathrm{H}_{2} \mathrm{O}_{2}$, the outer fraction of the meltwater can be used.

All analytical systems are continuous flow systems, i.e. the sample stream is analysed continuously. Valves are only necessary to switch between sample stream and calibration solutions. Reagents are added continuously to the sample stream using peristaltic pumps. Before and after every subcore sample, blank solutions are measured to define the baseline. All methods are linear in the relevant concentration ranges, and one-point calibrations are sufficient. The following analytical techniques were used:

$\mathrm{H}_{2} \mathrm{O}_{2}$ : Hydrogen peroxide was analysed by using the enzymatic-fluorometric technique described by Lazrus $e t$ al. (1986). Instead of ( $p$-hydroxyphenyl)acetic acid, 4-
Table 1

\begin{tabular}{lcc}
\hline Species & $\begin{array}{c}\text { Lower limit of detection } \\
(\mu \mathrm{mol})\end{array}$ & $\begin{array}{c}\text { Resolution* } \\
(\mathrm{mm} \text { ice) }\end{array}$ \\
\hline $\mathrm{H}_{2} \mathrm{O}_{2}$ & 0.05 & 12 \\
$\mathrm{HCHO}$ & 0.01 & 11 \\
$\mathrm{NH}_{4}{ }^{+}$ & 0.01 & 7 \\
$\mathrm{Ca}^{2+}$ & 0.05 & 35 \\
\hline
\end{tabular}

* The given resolution corresponds to the drop of a step function to the 1/e fraction (Sigg et al., 1992).

ethylphenol was added as substrate. A filter fluorimeter (326 nm/410 nm) with a Cadmium Lamp (Hamamatsu L2264) and a $25 \mu \mathrm{l}$ fluorescence cell (Hellma 178.010-OS40) that was fabricated in our laboratory were used as detectors.

$\mathrm{HCHO}$ : Formaldehyde is analysed using the Hantz reaction. The fluorometric method is adopted from Dong and Dasgupta (1987). Fluorescence is measured by means of a fluoroscence spectrophotometer $(412 \mathrm{~nm} / 510 \mathrm{~nm}$, Shimadzu RF350)

$\mathrm{NH}_{4}^{+}$: Ammonia is analysed using the reaction with ophthaldialdehydase (OPA). The fluorometric method is described in Genfa and Dasgupta (1989). The same type of detector $(365 \mathrm{~nm} / 425 \mathrm{~nm})$ as for $\mathrm{H}_{2} \mathrm{O}_{2}$ is applied.

$\mathrm{Ca}^{2+}$ : Calcium is analysed by an absorption technique, which is described in Kagenov and Jensen (1982). Because of the relatively low sensitivity, the absorption cell (Hellma $76.052-Q S)$ is rather large $(300 \mu$ l) yielding a poorer spatial resolution. Blank and standards are prepared in deionized water.

Table 1 lists the performances of the used analytical techniques.

\section{RESULTS AND DISCUSSIONS}

\subsection{An overview of the whole record}

Figure 1 shows an overview of the measured concentrations of the four components as a function of depth, the data were averaged over a $55 \mathrm{~cm}$ interval. The different climatic stages are indicated on the top of the figure. The time scale has been established by stratigraphic layer-counting of calcium, nitrate, dust and ammonium together with reference horizons (Johnsen et al., 1992). The climatic development from 40,000 years B.P. to present day conditions is characterized by the major transition from glacial conditions to the present interglacial stage. The glacial period, including the transition into the interglacial, is characterized by frequent changes from typically cold conditions to mild conditions over an extremely short depth interval, corresponding almost certainly to a time interval of at most a few tens of years. Almost all of these climatic changes are accompanied by large concentration changes of the measured species.

The $\mathrm{Ca}^{2+}$ concentration shows the clearest relation to the different climatic stages: low values in warm conditions, high values in cold conditions. During the different warm stages in the glaciation the $\mathrm{Ca}^{2+}$ concentration always shows the same low level 


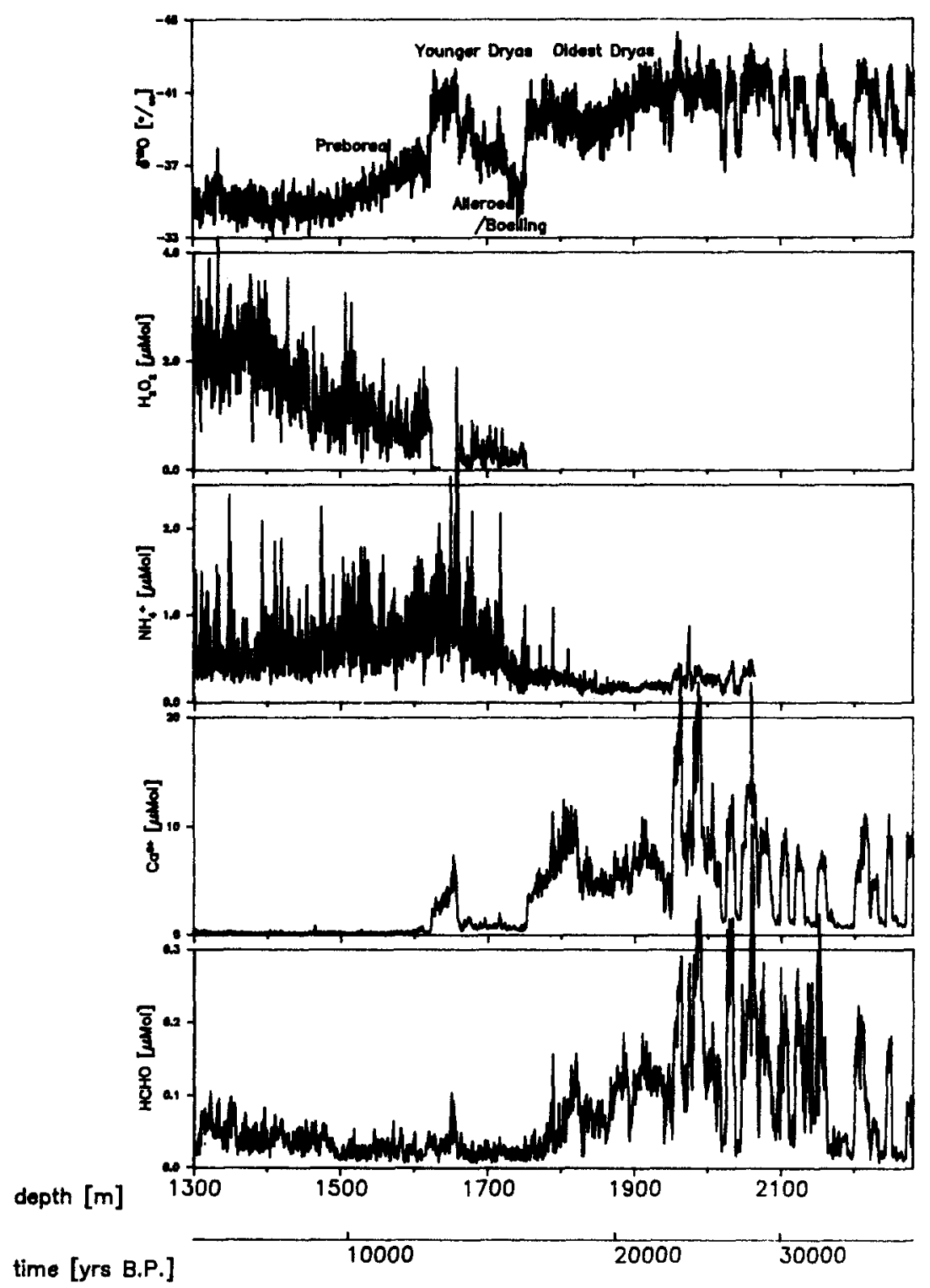

Fig. 1. Overview of the four species together with the preliminary time scale and the $\delta^{18} \mathrm{O}$ curve, the climatic stages are indicated (mean values over $55 \mathrm{~cm}$ ).

around $1 \mu \mathrm{mol}$ with a rather small absolute variability compared to the cold stages (see Fig. 5a). The level in the warm stages, however, is still 3-5-times higher than the mean Holocene concentration.

For irreversibly deposited species the flux (concentration times accumulation rate) is a better measure for the atmospheric load than is the concentration alone (Stauffer and Neftel, 1988; Herron, 1982). This means that with a constant atmospheric loading, a decrease in the accumulation rate implies increasing concentrations in the ice. Therefore, part of the change in the concentration has to be attributed to corresponding changes in the accumulation rate. During the last transition from the glaciation into the Holocene, the change in annual layer thickness indicates a change in the accumulation rate by a factor of $2-3$ (Johnsen et al., 1992), whereas the $\mathrm{Ca}^{2+}$ concentration changes by a factor of 10 ; thus the atmospheric load of aerosols containing calcium was higher in the cold stages. Soil-derived carbonate particles are the most likely source (Cragin et al., 1977). Probable reasons for the enhanced loading of the atmosphere with $\mathrm{Ca}^{2+}$ containing particles include the exposure of sea shelves as a result of lower ocean level, increased aridity and the larger latitudinal temperature gradient during the cold stages causing stronger winds.

The $\mathrm{H}_{2} \mathrm{O}_{2}$ concentration shows the opposite picture. $\mathrm{H}_{2} \mathrm{O}_{2}$ is only preserved in sections of polar ice 
from Greenland having low impurity levels. Ice from the cold stage has a much higher dust load, causing a quantitative decay of $\mathrm{H}_{2} \mathrm{O}_{2}$ and a consequent loss of information on the atmospheric content of $\mathrm{H}_{2} \mathrm{O}_{2}$ during the cold stages. During the warm stages, layers with elevated dust levels (indicated by $\mathrm{Ca}^{2+}$ peaks) show low $\mathrm{H}_{2} \mathrm{O}_{2}$ concentrations. The mechanism and the rate of the decay process are still unknown. A detailed investigation by Sigg on the $300 \mathrm{~m}$ Eurocore drilled in 1989 at Summit revealed a decay rate of about $1 \%$ per 100 yr of the mean concentration (Sigg and Neftel, 1991). Decays exceeding 50\% have therefore to be expected for ice older than $5000 \mathrm{yr}$ assuming that the dust level has not significantly changed. However, the strong decrease in $\mathrm{H}_{2} \mathrm{O}_{2}$ with increasing age in the early Holocene (more than $50 \%$ in less than 1000 years) indicates that the lower $\mathrm{H}_{2} \mathrm{O}_{2}$ concentration between 9000 and 11,000 years could also be of atmospheric origin, which would be in agreement with a lower $\mathrm{OH}$ content suggested by Staffelbach $e t$ al. (1991).

The continuous HCHO measurements show dramatically different behaviour from previous measurements from the Dye 3 core and the Byrd core (Staffelbach et al., 1991). The HCHO values show variations that parallel the $\mathrm{Ca}^{2+}$ concentration in most of the cold stages. The $\mathrm{HCHO}$ concentrations of the few discrete samples from glacial cold stages along the Dye 3 core measured by Staffelbach did not show this feature and were roughly one order of magnitude lower than samples with a similar age from the Summit core.

The ammonium concentration is influenced by two important features: seasonal variation and high peaks caused by biomass burning events (Legrand et al, 1992) superimposed on summer values. The lower values in the glaciation imply a corresponding lower atmospheric concentration over Greenland (the lower accumulation in the glaciation would require an opposite trend, if the load had been constant). This can be explained as a result of the colder climate, which reduces in general the biological activity. However, the concentrations in the Younger Dryas are roughly one order of magnitude higher than those in the glacial maximum. This suggests that the Younger Dryas was not a full return to glacial conditions.

During the last stage of the glaciation (above 1700 $m$ ) the mean ammonium concentration starts to increase again. The concentration between $1800 \mathrm{~m}$ and $1750 \mathrm{~m}$ is double that between $1950 \mathrm{~m}$ and $1850 \mathrm{~m}$. Without further analysis it cannot be distinguished whether this is parallel behaviour with a decreasing accumulation rate, whether it is a first sign of a general change of the climatic system enhancing the biological productivity, or if it is caused by a change in the general circulation pattern, which determines the effectiveness of the transport to Greenland. A systematic analysis of the covariation with the accumulation rate and other chemical parameters is required to clarify this point.

\subsection{Specific features}

4.2.1. Seasonal variations. In the following we discuss some specific features, taking advantage of the high resolution of the analysis. Figure 2 shows a detailed picture from the depth interval at $1401 \mathrm{~m}$ corresponding to a time period of $7 \mathrm{yr} . \mathrm{Ca}^{2+}, \mathrm{NH}_{4}^{+}$ and $\mathrm{H}_{2} \mathrm{O}_{2}$ show a regular seasonal fluctuation. For $\mathrm{Ca}^{2+}$ a clear seasonal variation is found, with a maximum in spring (Whitlow et al., 1992), that most probably originates in big Asian dust storms (Merril et al., 1989; Gao et al., 1992). The winter Arctic aerosol has also been suggested as an explanation (Whitlow et al., 1992). The seasonal maxima of $\mathrm{Ca}^{2+}$ are indicators for ice strata with enhanced dust levels, which cause a slow decay of the $\mathrm{H}_{2} \mathrm{O}_{2}$. Therefore, a reversed "seasonality" is established in the $\mathrm{H}_{2} \mathrm{O}_{2}$ concentration, which varies in antiphase with the $\mathrm{Ca}^{2+}$ concentration. The fraction of $\mathrm{H}_{2} \mathrm{O}_{2}$ loss is only weakly correlated with the $\mathrm{Ca}^{2+}$ concentration, which indicates that the $\mathrm{H}_{2} \mathrm{O}_{2}$ is not reacting directly with calcium.

The seasonality found in the $\mathrm{NH}_{4}^{+}$concentrations shows a maximum concentration in summer and minimum concentrations close to zero in winter (Staffelbach, 1990). This can be explained by biological activity in soils, which increases with temperature (Warneck, 1988). As it has to be expected, a phase shift can be seen between the $\mathrm{NH}_{4}^{+}$and $\mathrm{Ca}^{2+}$ concentration maxima in a large fraction of the years.

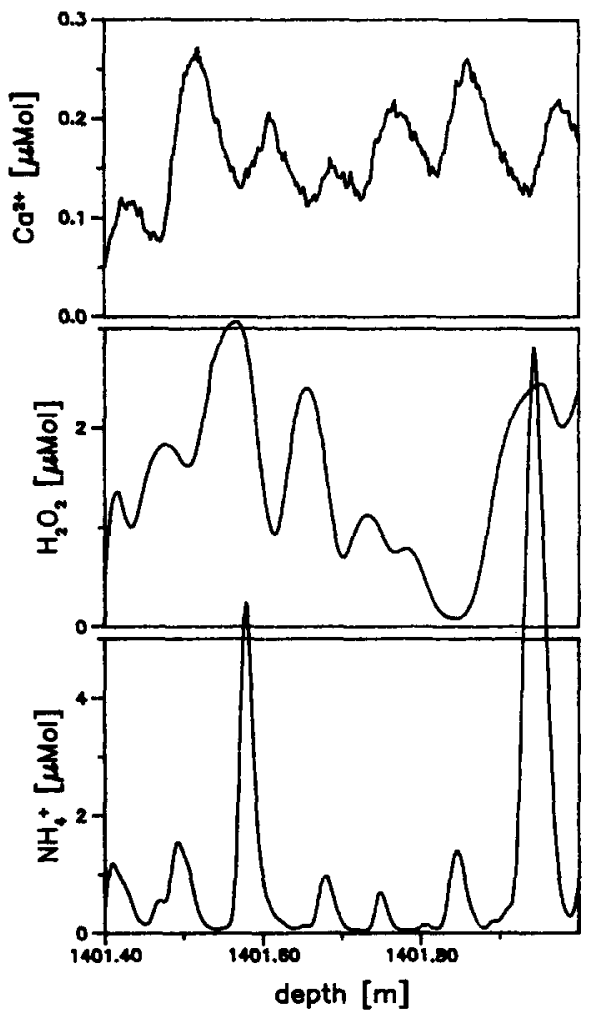

Fig. 2. Seasonal variation of $\mathrm{NH}_{4}^{+}, \mathrm{Ca}^{2+}$ and $\mathrm{H}_{2} \mathrm{O}_{2}$ during the Holocene at around $8800 \mathrm{yr}$ B.P. The illustrated interval contains $7 \mathrm{yr}$. 
4.2.2. Signs of biomass burning events. Figure 3 shows a few of the large $\mathrm{NH}_{4}^{+}$spikes, which have been shown to be caused by biomass burning events (Legrand et al., 1992). Enhanced $\mathrm{H}_{2} \mathrm{O}_{2}$ and $\mathrm{HCHO}$ levels are often found associated with these peaks. Biomass burning events are emitting not only $\mathrm{NH}_{3}$, but also large quantities of hydrocarbons. During transport to Greenland these hydrocarbons will be oxidized, contributing to an additional volume source of $\mathrm{H}_{2} \mathrm{O}_{2}$, $\mathrm{HCHO}$ and organic acids to the atmosphere that is recorded in the ice. (The peak broadening of $\mathrm{H}_{2} \mathrm{O}_{2}$ and $\mathrm{HCHO}$ relative to the $\mathrm{NH}_{4}^{+}$is due to the smoothing process after deposition.)

The high concentration $\mathrm{NH}_{4}^{+}$spikes are also found during the cold stages. During the Oldest Dryas (20,000-15,000 yr B.P.) the frequency is lower; however, during the Younger Dryas they still occur quite often. This indicates that air masses from further south must have reached central Greenland, because large parts of the North American continent were ice covered at that time.

The seasonality of the measured compounds can be followed down through the Holocene and also through the Alleroed/Boelling. During the Younger and part of the Oldest Dryas, $\mathrm{Ca}^{2+}$ and $\mathrm{NH}_{4}^{+}$data, corrected for the dispersion in the measuring system, are still in agreement with other seasonally varying parameters such as nitrate and dust that have been measured with very high spatial resolution by our Danish colleagues on selected core sections. However, a clear phase shift can no longer be distinguished.

4.2.3. The Younger Dryas event. The most recent dramatic change from a colder into a warmer climatic

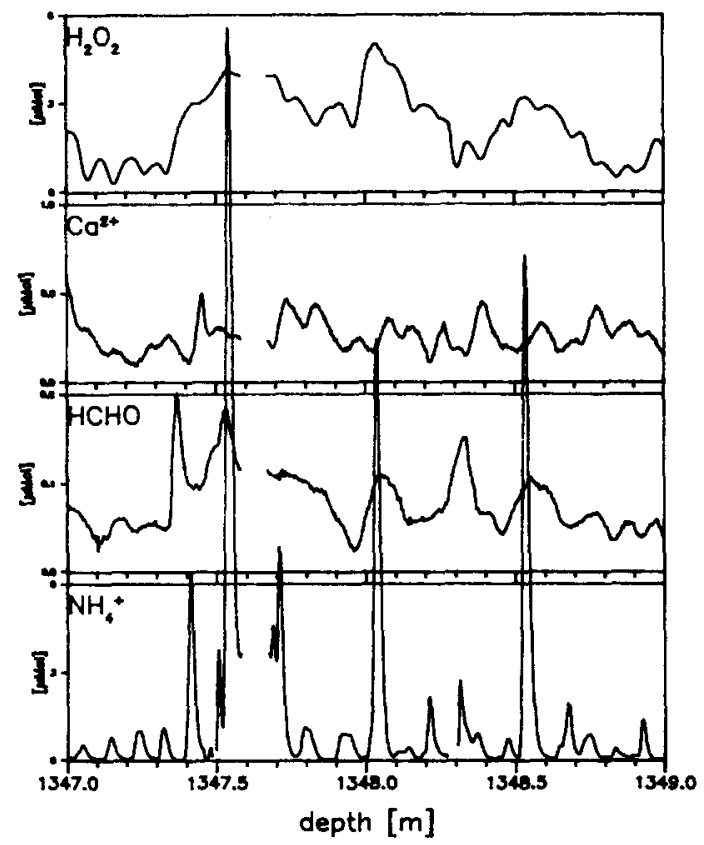

Fig. 3. Large $\mathrm{NH}_{4}^{+}$spikes and increased levels of $\mathrm{H}_{2} \mathrm{O}_{2}$ and $\mathrm{HCHO}$ caused by biomass burning, around $8300 \mathrm{yr}$ B.P. regime occurred at a depth of $1625 \mathrm{~m}$ : the transition from the Younger Dryas into the Preboreal. The combined information of continuous $\delta^{18} \mathrm{O}$, dust, and nitrate measurements with the records presented in this paper allowed a precise dating of the duration and onset of the Younger Dryas (Johnsen et al, 1992). The onset was dated to $12,700 \mathrm{yr}$ B.P. and the end to 11,550 yr B.P. Figure 4 shows three intervals covering the beginning (1657-1661 m) a middle section (1647$1651 \mathrm{~m})$ and the end $(1622-1627 \mathrm{~m})$. The most notable feature is the extremely short time intervals over which the transition occurs. At the end of the Younger Dryas a 10-fold change in the $\mathrm{Ca}^{2+}$ concentration from a level above $2 \mu \mathrm{mol}$ to below $0.2 \mu \mathrm{mol}$ occurred within less than two decades. This implies dramatic changes not only on the climatic time scale but also on the meteorological time scale. During the first part of the Younger Dryas a strong correlation between $\mathrm{HCHO}$ and $\mathrm{Ca}^{2+}$ is established; however, this is lost within a few years in the middle of the Younger Dryas. At present we cannot offer an explanation of what causes the covariation of the $\mathrm{HCHO}$ concentrations with the $\mathrm{Ca}^{2+}$ concentrations. We hope that more detailed chemical analysis may provide some clues to the mechanisms involved. Further research is required to investigate whether alkaline snow and ice enhance the absorption of gaseous $\mathrm{HCHO}$, or whether $\mathrm{HCHO}$ is brought in with the aerosols. Nevertheless, we would like to emphasize that in the late glacial, in the beginning of the Boelling and at the end of the Younger Dryas in the Summit core, similar low $\mathrm{HCHO}$ values were found in the Summit and the Dye 3 cores; so the conclusion drawn by Staffelbach et al., (1991), leading to a lower $\mathrm{OH}$ radical concentration of the atmosphere during the glaciation, is not excluded.

4.2.4. Oscillations during the glaciation. Figure 5 shows two sequences from the last glaciation. Both intervals contain around $140 \mathrm{yr}$. Figure 5 a represents a transition from a cold into a mild stage at around $26,000 \mathrm{yr}$ B.P. The concentration changes in $\mathrm{Ca}^{2+}$ occur in two steps, each of them taking place within 5 to $10 \mathrm{~cm}$. The annual layer thickness at this depth is around $2 \mathrm{~cm}$, which means that the changes in concentration happen within $5 \mathrm{yr}$ or less. $\mathrm{HCHO}$ values reach $0.4 \mu \mathrm{mol}$. This is higher than present day concentrations in fresh fallen summer snow, which were believed to be the highest because of the adsorbed and trapped $\mathrm{HCHO}$ on the snow during its formation (Staffelbach, 1990). $\mathrm{Ca}^{2+}$ and HCHO show a strong covariation, which suggests a contribution of $\mathrm{HCHO}$ from an aerosol source, either directly or by an enhanced reaction on the aerosol surface. In the Dye 3 core such high concentrations did not show up in the analysed sections from the cold stages, suggesting that the aerosol characterization was not uniform over Greenland during the cold stages.

Figure $5 \mathrm{~b}$ shows a warm stage at around $32,000 \mathrm{yr}$ B.P. It is one of the few exceptions where the HCHO concentrations are very high, while the $\mathrm{Ca}^{2+}$ concen- 


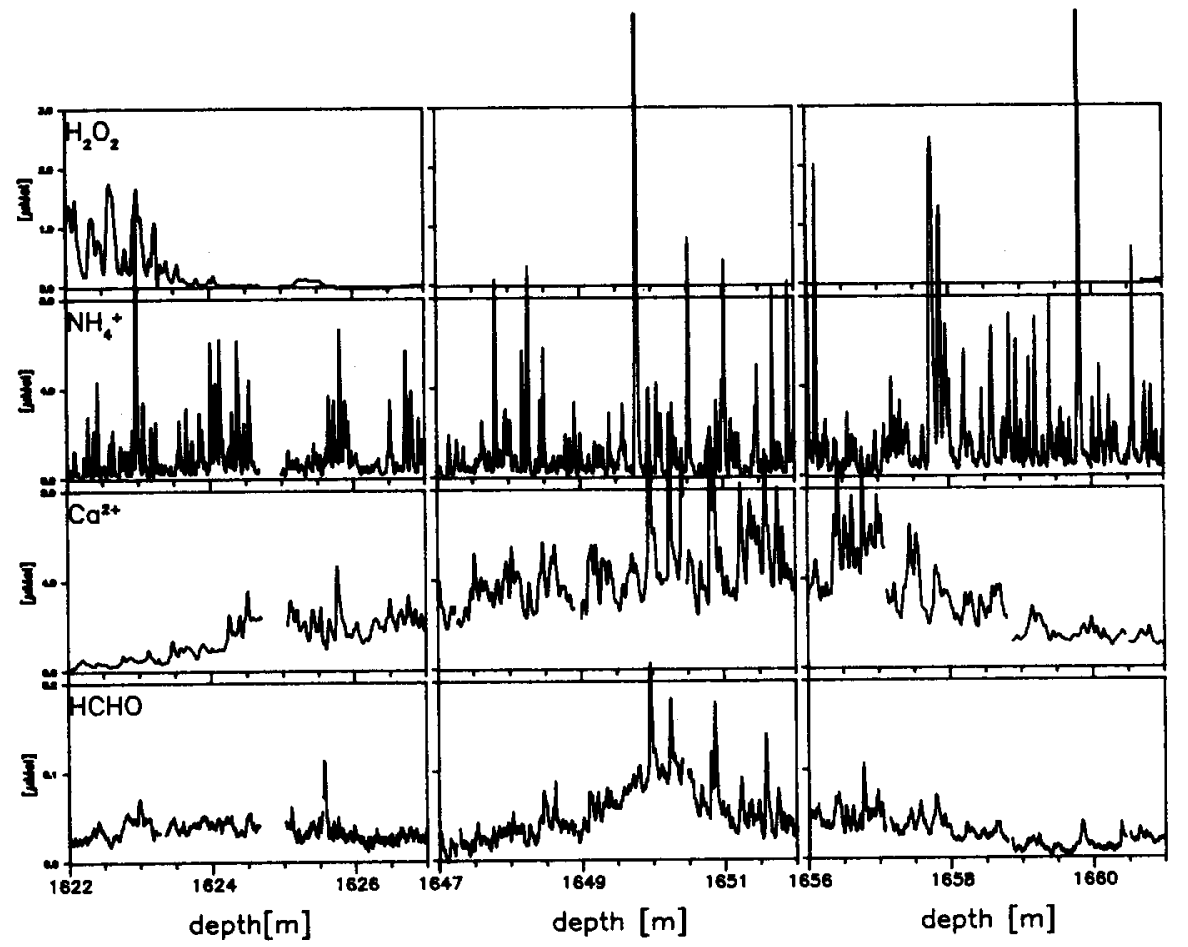

Fig. 4. Three sequences from Younger Dryas, covering the beginning (at ca. 12,500 yr B.P.), the middle part (at ca 12,200 yr B.P.) and the end of the cold period (at ca. 11,500 yr B.P.). The first two intervals contain around $150 \mathrm{yr}$, the last contains around $110 \mathrm{yr}$.

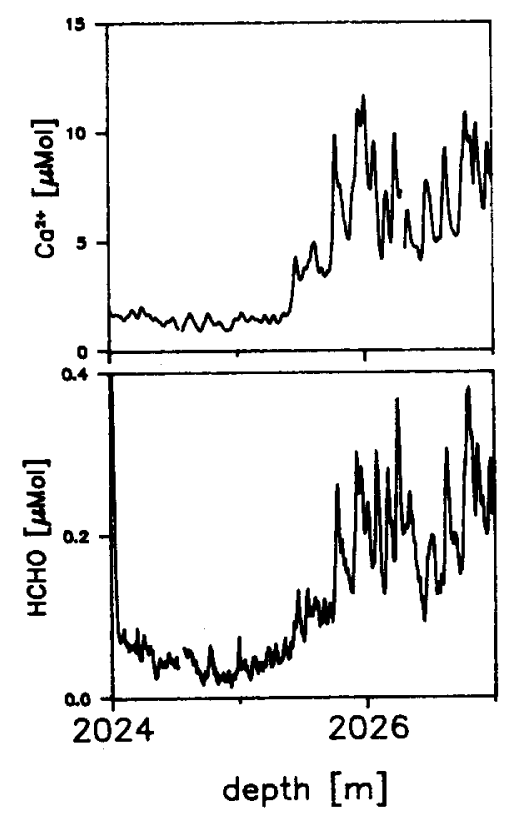

a.

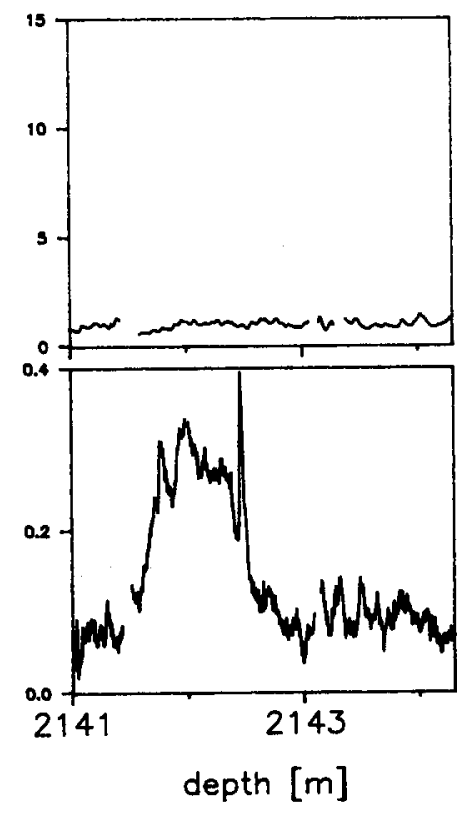

b.

Fig. 5. Two sequences from the Oldest Dryas of $\mathrm{HCHO}$ and $\mathrm{Ca}^{2+}$. (a) Transition from a cold into a warm stage at around 25,000 yr B.P. (b) Warm stage with high HCHO concentrations at around 31,000 yr B.P. Both intervals contain around 140 


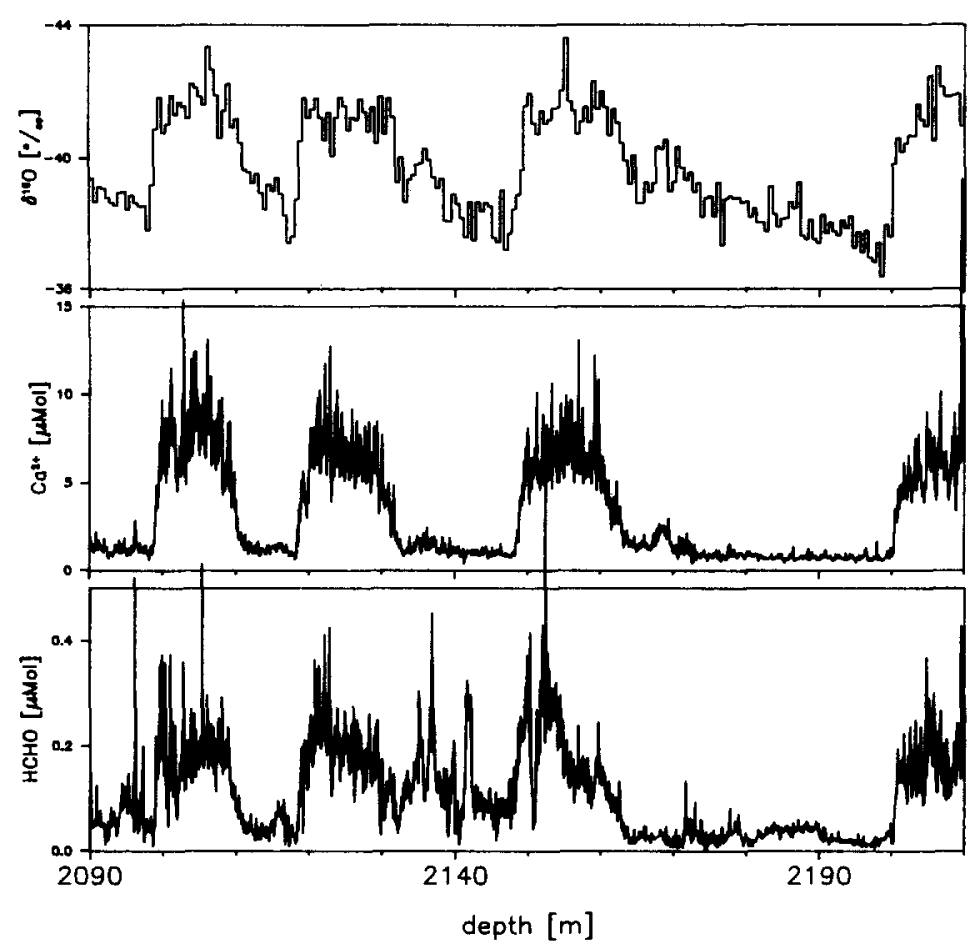

Fig. 6. Several rapid variations of $\mathrm{Ca}^{2+}$ and $\mathrm{HCHO}$ covering the time interval between 29,000 and 35,000 yr B.P. compared with the feature of the $\delta 180$ record.

tration is low. The high HCHO peak at $2142 \mathrm{~m}$ lasts about 40-60 yr. Thus a single precipitation event could not have caused the observed peak.

Figure 6 shows a typical sequence exhibiting periodic oscillations within the glaciation period (2160 -2200 m.). Three features are common to all the oscillations found between 40,000 and $20,000 \mathrm{yr}$ B.P.: (i) the transition from the warmer into the colder stage occurs on a longer depth interval than the termination of the cold stage, reflecting most probably also an asymmetry in the involved time scales. (ii) $\mathrm{Ca}^{2+}$ and $\delta^{18} \mathrm{O}$ show distinct trend differences and (iii) the strong coupling between $\mathrm{HCHO}$ and $\mathrm{Ca}^{2+}$ holds only for the cold stages.

The $\delta^{18} \mathrm{O}$ ratio, an excellent temperature indicator, exhibits a slow and steady decrease from the mild stage to the cold stage, whereas the $\mathrm{Ca}^{2+}$ concentration jumps much later to the high cold stage. Both parameters are in phase during the termination of the warm phase. A shift of the polar front has been suggested as an explanation (Dansgaard et al., 1984) for the $\delta^{18} \mathrm{O}$ variations. It has to be investigated in comparison with additional chemical data if the southwards moving polar front can create such a trigger effect for the $\mathrm{Ca}^{2+}$ input to the polar region, and where the asymmetry in the transition behaviour comes from. A dilution of the precipitation source by isotopically light melting water, which would decrease the $\delta^{18} \mathrm{O}$ ratio during the mild stages and explain the different feature of the $\mathrm{Ca}^{2+}$ concentration has been excluded due to the deuterium excess (Johnsen et al., 1989).

\section{CONCLUSIONS}

The continuous record of $\mathrm{H}_{2} \mathrm{O}_{2}, \mathrm{HCHO}, \mathrm{NH}_{4}^{+}$and $\mathrm{Ca}^{2+}$ concentrations from the section of the Summit ice core, which covers the time period from $8000-38,000$ years B.P., show characteristic patterns that illustrate climatic changes. The concentration changes in the ice core cannot be explained simply by a cause and effect relationship with the past climate. The climatic system is highly underdetermined by the available information. The presented data clearly show that on time scales of only a few decades, the Earth's climatic system must have changed considerably. A simplified picture of two stable climatic stages - cold and warm-is not satisfactory for a description of the evolution of the climate over the last $40,000 \mathrm{yr}$.

Acknowledgements-The deep ice core at Summit was obtained by the Greenland Ice Core Project (GRIP) and ESF associate programme, with Belgium, Denmark, France, Germany, Great Britain, Iceland, Italy and Switzerland participating. The laboratory work was supported by the Swiss National Science Foundation and the Department of Energy. We thank Markus Möll for his great effort in providing the continuous profiles in the field. Roget Bales helped us to convert "Swiss English" into a scientifically widely accepted language. We are grateful to the two reviewers whose helpful comments improved the paper. 


\section{REFERENCES}

Cragin J. H., Herron M. M., Langway C. C. Jr and Klouda G. (1977) Interhemispheric comparison of changes in composition of atmospheric precipitation during the late cenzoic area. Polar Oceans (edited by Dunbar M. J.), pp. 617-631. Calgary: Arctic Institute of North America.

Dansgaard W., Johnsen S. J., Clausen H. B., Dahl-Jensen D., Gunderstrup N., Hammer C. and Oeschger H. (1984) North Atlantic climatic oscillations revealed by deep Greenland ice cores. In Climate Processes and Climate Sensitivity. Geophysical Monograph 29, pp. 288-298. AGU, Washington DC.

Delmas R. J (1993) A natural artefact in Greenland ice core $\mathrm{CO}_{2}$ measurements. Tellus (in press).

Dibb, J. E., Jaffrezo J.-L. and Legrand M. (1992) Initial findings of recent investigations of air-snow relationships in the Summit region of the Greenland Ice Sheet. J. atmos. Chem. 14, 167-180.

Dong S. and Dasgupta P. K. (1987) Fast fluorometric flow injection analysis of formaldehyde in atmosphere water Envir. Sci. Technol. 21, 581-588.

Gao Y., Arimoto R., Zhou M. Y., Merrill J. T. and Duce R. A (1992) Relationship between dust concentrations over eastern Asia and the remote north Pacific. J. geophys. Res. 97, 9867-9872

Genfa Z. and Dasgupta P. K. (1989) Fluorometric measurement of aqueous Ammonium ion in a flow injection system. Analyt. Chem. 61, 408-412.

Herron M. M. (1982) Impurity sources of $\mathrm{F}^{-}, \mathrm{Cl}^{-}, \mathrm{NO}_{3}^{-}$and $\mathrm{SO}_{4}^{2-}$ in antarctic precipitation. J. geophys. Res. 87, 3052-3060.

Johnsen S., Dansgaard W. and White J. W. C. (1989) The origin of Arctic precipitation under present and glacial conditions. Tellus 41B, 452-468.

Johnsen S. F., Clausen H. B., Dansgaard W., Fuhrer K., Gunderstrup N., Hammer C. U., Iversen P., Jouzel J., Stauffer B. and Steffensen J. P. (1992) Irregular glacial interstadials recorded in a new Greenland ice core. Nature 359, 311-313.

Kagenov I. and Jensen W. (1983) Kinetic determination of magnesium and calcium by stopped flow injection analysis. Analyt. Chim. Acta 145, 125-133.

Kleinmann L. I. (1986) Photochemical formation of peroxides in the boundary layer. J. geophys. Res. 91, $10,889-10,904$

Lazrus A. L., Kok G. L., Lind J. A., Gitlin S. N., Heikes B. G. and Shetter R. E. (1986) Automated fluorometric method for hydrogen peroxide in air. Analyt. Chem. 58, 594-597. Legrand M., De Angelis M., Staffelbach T., Neftel A. and Stauffer B. (1992) Large perturbations of ammonium and organic acids content in the Summit-Greenland ice core, fingerprint from forest fires? Geophys. Res. Letts. 19, 473-475.

Merrill J. T., Uematsu M. and Bleck R. (1989) Meterological analysis of long range transport of mineral aerosol over North Pacific. J. geophys. Res. 94, 8584-8598.

Oeschger H. and Langway C. C. Jr (Editors) (1989) The Environmental Record in Glaciers and lice Sheets.

Sigg A. and Neftel A. (1991) Evidence for a $50 \%$ increase in $\mathrm{H}_{2} \mathrm{O}_{2}$ over the past 200 years from a Greenland ice core. Nature 351, 557-559.

Sigg A., Staffelbach T. and Neftel A. (1992) Gas phase measurements of hydrogen peroxide in Greenland and their meaning for the interpretation of $\mathrm{H}_{2} \mathrm{O}_{2}$ records in ice cores. J. atmos. Chem. 14, 223-232.

Sigg A., Fuhrer K., Anklin M. and Staffelbach T. (1993) A continuous analysis technique for chemical trace species in polar ice cores. Envir. Sci. Technol. (accepted for publication).

Staffelbach T. (1990) Formaldehyd- und Ammonium-Messungen and Schnee, Firn- und Eisproben aus polaren and alpinen Regionen. Ph.D thesis, University of Bern.

Staffelbach T., Neftel A., Stauffer B. and Jacob D. (1991) Formaldehyde in polar ice cores; a possibility to characterize the atmospheric sink of methane in the past. Nature $349,603-605$.

Stauffer B. and Neftel A. (1988) What have we learned from the ice cores about atmospheric changes in the concentrations of nitrous oxide, hydrogen peroxide, and other trace species. In The Changing Atmosphere (edited by Rowland F. S. and Isaksen I. S. A.), pp. 63-77. John Wiley, Dahlem Konferenzen 1988.

Thompson A. M. (1992) The oxidizing capacity of the earth's atmosphere: probable past and future changes. Science 256, 1157-1165.

Thompson A. M., Owens M. A. and Stewart R. W. (1989) Sensitivity of tropospheric hydrogen peroxide to global chemical and climate change. Geophys. Res. Letts. 16, 53-56.

Warneck P. (1988) Chemistry of the Natural Atmosphere. Academic Press, San Diego, California.

Whitlow S., Mayewski P. A. and Dibb J. E. (1992) A comparison of major chemical species seasonal concentration and accumulation at the South Pole and Summit, Greenland. Atmospheric Environment 26A, 2045-2054. 